\title{
What's in a Label?
}

\author{
JAMES C. HATHAWAY*
}

One of the most striking features of the international refugee regime as it has evolved over the last quarter century is the proliferation of labels. Rather than simply assessing the circumstances of applicants against the Convention refugee definition, the governments of most developed states have instead invented a seemingly endless list of alternative statuses - "B" status, humanitarian admission, temporary protected status, special leave to remain, Duldung, and the like. Persons assigned one of these labels have generally been protected against refoulement in line with Article 33 of the Refugee Convention. But in a variety of other ways, they have not been treated as refugees.

They have, in particular, faced limits on freedom of movement, the ability to earn a livelihood, and access to education and general social support systems. Most critically, there has been a near-universal association of alternative status with non-permanent presence. While refugees are by and large granted "asylum" - understood to entail an enduring right to remain in, or to be enfranchised by, the host country - the beneficiaries of alternative forms of protection have usually been admitted instead to what is commonly called "temporary" protection. That is, they are not granted an indefinite right to remain, but are instead allowed to stay in the host state for the duration of the risk in their country of origin.

In pursuing this dual track approach, developed states have laboured under two fundamental misunderstandings.

First, the approach is apparently driven in large part by a belief that recognition of Convention refugee status is a legal fetter on the right of governments to bring protection to an end when and if circumstances in the

* Professor of Law and Director, Program in Refugee and Asylum Law, University of Michigan; Senior Visiting Research Associate, Refugee Studies Programme, Oxford University. This paper is based on a speech delivered in Potsdam to the Conference on A Single, Fair and Efficient Asylum Procedure, sponsored by the Centre for International and European Law on Immigration and Asylum of the University of Konstanz and the Human Rights Centre of the University of Potsdam. Hemme Battjes of Vrije Universiteit Amsterdam kindly provided assistance in updating the analysis to take account of developments up to January 2003. Most of the positions taken here will be developed in detail in The Rights of Refugees Under International Law (Cambridge University Press, forthcoming 2004). 
country of origin allow. As a matter of international law, this is not so. A link between refugee status and "asylum" was rejected both in the drafting of the Refugee Convention and at the 1977 Territorial Asylum Conference. ${ }^{1}$ Moreover, the cessation clauses in Art. 1(C)(5-6) of the Convention make it absolutely clear that refugee status entails simply a duty to protect so long as a well-founded fear of being persecuted persists - ironically one of the key goals pursued by establishment of the alternative labels. Granted, the dissociation of refugee status and asylum would be contested at the level of politics and domestic law in some states. But the crucial point is that, as a matter of international law, there was and is no impediment to seeing refugee status as requiring only protection for the duration of risk. ${ }^{2}$ Refugee status is not a legal constraint on the right of states to define their own immigration policies.

Second and conversely, there is no legal magic in the various alternative protection labels assigned by states. Because the recognition of refugee status is simply a declaratory, not a constitutive act, a person is a refugee with entitlement to Convention rights as soon as he or she in fact meets the refugee definition. ${ }^{3}$ The decision of a reception state to label a refugee as something else is, as matter of international law, quite irrelevant. If the individual is in fact a refugee as defined by the Convention, even if not yet recognized as such, he or she must be treated with respect for the system of incremental entitlement established by the Refugee Convention. ${ }^{4}$ A government may not rely on its decision to delay or avoid verification of refugee status in order to circumvent respect for rights which are, as a matter of international law, its duty to uphold. ${ }^{5}$

This does not mean that every right set out in Arts. 2-34 of the Convention must be immediately granted to any person who claims to be a refugee. To the contrary, the Convention strikes a neat balance between the needs of refugees and the legitimate concerns of state parties. While all refugees under a state

1 See generally A. Grahl-Madsen, Territorial Asylum (1980). I summarize the contemporary significance of the abortive effort to draft a binding commitment to grant asylum in The Law of Refugee Status (1991) ("Refugee Status"), at pp. 13-16.

$2 \mathrm{My}$ analysis of why refugee law requires only protection for the duration of risk is set out in "The Meaning of Repatriation," (1997), 9(4) International Journal of Refugee Law, pp. 551-558; also published in European University Institute ed., Legal and Policy Issues Concerning Refugees from the Former Yugoslavia, pp. 4-11 (1997).

3 See text infra at note 34 .

4 I explain the nature of this rights regime, including what I refer to as its incremental "attachment system", in "The International Refugee Rights Regime", (2000), 8(2) Collected Courses of the Academy of European Law, pp. 91-139 ("Refugee Rights Regime").

5 "A state may not invoke the provisions of its internal law as justification for its failure to perform a treaty", Vienna Convention on the Law of Treaties, 1155 UNTS 331, entered into force 27 January 1980 ("Vienna Convention"), at Art. 27. 
party's authority benefit from a number of core rights, additional entitlements accrue as a function of the nature and duration of the attachment to the reception state. Some rights inhere as soon as the refugee enters a state party's territory; others only when the refugee is lawfully within the territory; another set when the refugee is lawfully staying there; and a few rights accrue only upon satisfaction of a durable residency requirement. ${ }^{6}$

Nor are most refugee rights granted on an absolute basis. Instead, refugee rights are normally defined on a contingent basis, meaning that refugees are entitled to the benefit of a given right only to the extent it is enjoyed by some other group. ${ }^{7}$ For example, refugees have the same right to primary education as citizens of the host state. ${ }^{8}$ But they are entitled to work only on the same terms as most favoured foreigners, ${ }^{9}$ and must have access to public housing only when that right is granted to aliens generally. ${ }^{10}$ Subtle analysis is therefore required to determine precisely what protections are owed to a refugee, including an assessment of both the particular refugee's level of attachment and the content of the contingent standard which governs the rights in question.

The essential point often misunderstood in the elaboration of alternative protection regimes is that while the Convention does not require states formally to determine refugee status, neither does it authorize governments to withhold rights from persons who are, in fact, refugees just because status assessment has not taken place. ${ }^{11}$ This is because the decision not to authenticate refugee status - whether generally or as an exceptional measure must be analyzed against the backdrop of the government's legal duty to grant convention rights to all persons under its jurisdiction who are in fact refugees. ${ }^{12}$ A state that wishes to protect itself against the possibility of

6 The structure is incremental because the levels build on one another (a refugee lawfully present is also present; a refugee lawfully residing is also lawfully present; and a refugee durably residing is also lawfully residing). Rights once acquired are retained for the duration of refugee status.

7 See Refugee Rights Regime, supra note 4, for an elaboration of the nature of contingent and absolute rights.

8 Convention relating to the Status of Refugees, 189 UNTS 137, entered into force 22 April 1954 ("Refugee Convention"), at Art. 22(1).

9 Refugee Convention, supra note 8, at Art. 17(1).

10 Ibid., at Art. 21.

11 The decision on how to identify refugees is a matter within the discretion of each state party: United Nations High Commissioner for Refugees, Handbook on Procedures and Criteria for Determining Refugee Status (1979, re-edited 1992) (“Handbook"), at para. 189.

12 In essence, a general or situation-specific decision by a state party not to verify refugee status amounts to an implied authorization for Convention refugees to seek protection without the necessity of undergoing a formal examination of their claims. This approach reflects the reality of refugee protection in much of the less developed world. 
receiving non-genuine claims is, of course, free to establish and operate a procedure to verify the refugee status of those who seek its protection. If, however, a state opts to delay or to dispense with adjudication of the status of persons who claim to be Convention refugees, it must be taken to have acquiesced in their assertion of entitlement to refugee rights, and provisionally grant the refugee status claimants at least the Convention rights which inhere prior to a decision having been reached to authorize the refugee to stay in its territory. ${ }^{13}$

Thus, any person in a state party's territory who in fact meets the refugee definition is entitled to protection against refoulement and discrimination, access to a state's courts, religious freedom, respect for property interests, and to partake in rationing and primary education systems. Such persons are entitled to be documented as having claimed refugee protection, they are to receive administrative assistance, penalties on account of their illegal entry or presence are prohibited, and restrictions on internal freedom of movement must be strictly provisional and justifiable. ${ }^{14}$ Moreover, persons who are in fact refugees, though allowed to remain on the basis of one of the alternative protection labels, are also refugees "lawfully present". As such they acquire the rights to engage in self-employment, to enjoy internal freedom of movement, and to be protected against expulsion. ${ }^{15}$

Indeed, where the so-called "temporary protection" systems authorize a person who is in fact a refugee to remain on an ongoing basis, refugees are further entitled to claim the benefit of those rights which accrue at the next level of attachment, "lawful stay". This is because the notion of "lawful

13 These are the rights that inhere in refugees without qualification, as well as those rights that are acquired by refugees who are "in" or "lawfully in" a state party's territory. By provisional grant, I mean that the duty to recognize these rights comes to an end if and when a final decision is reached that the individual in question is not a Convention refugee.

14 A significant number of rights are attributed to "refugees" without qualification of any kind: see Refugee Convention, supra note 8, at Arts. 3 ("non-discrimination"), 12 ("personal status"), 13 ("movable and immovable property"), 16(1) ("access to courts"), 20 ("rationing"), 22 ("education"), 29 ("fiscal charges"), 33 ("prohibition of expulsion or return - "refoulement"). Several other rights accrue to all refugees who are simply "in" or "within" a contracting state's territory: see Refugee Convention, supra note 8, at Arts. 4 ("religion"), 25 ("administrative assistance"), 27 ("identity papers"), 31(1) ("non-penalization for illegal entry or presence") and 31(2) ("movements of refugees unlawfully in the country of refuge"). In most cases, these formulations amount to the same thing: any refugee physically present, lawfully or unlawfully, in territory under a state's jurisdiction may invoke these rights. But rights which accrue at the first level of attachment are also owed when a state asserts jurisdiction over refugees not in its territory, eg. on the high seas. See my "Refugee Law is Not Immigration Law," (2002) Canadian Council on International Law Proceedings 134-157, edited version reprinted in (2002) World Refugee Survey, pp. 38-45.

15 See Refugee Convention, supra note 8, at Arts. 18 ("self-employment"), 26 ("freedom of movement"), and 32 (“expulsion"). 
stay" is not predicated on a formal declaration of refugee status, grant of the right of permanent residence, or establishment of domicile. As the drafters of the Convention emphasized, it is the refugee's de facto circumstances which determine whether or not this level of attachment is satisfied. ${ }^{16}$ They insisted that the notion of lawful stay ("résidence régulière") is "very wide in meaning ... [and] implie[s] a settling down and, consequently, a certain length of residence". ${ }^{17}$ As a practical matter, Grahl-Madsen therefore concluded that lawful stay may be implied from an officially tolerated stay beyond the last date that an individual is allowed to remain in a country without securing a residence permit. ${ }^{18}$ These additional rights include freedom of association, the right to engage in wage-earning employment and to practice a profession, access to housing and welfare, protection of labour and social security legislation, intellectual property rights, and to receive travel documentation. ${ }^{19}$

In sum, if the goal of the various alternative protection labels and their accompanying "temporary" protection systems is to avoid the need to recognize most Convention rights, they are legally untenable. And if their goal is instead to avoid the need to grant asylum, they are legally unnecessary. Under international law, the alternative labels grant states no broader discretion to withhold rights than does formal recognition of refugee status, and formal recognition of refugee status does not require governments to grant asylum

16 "[T]here were two alternatives: either to say 'résidant régulièrement' and 'lawfully resident,' or to say 'lawfully' in which case 'résidant' must be omitted, otherwise, there would be too many complications in the translation of the various articles. ... [I]t would be better to say 'régulièrement,' since 'légalement' seemed too decidedly legal ....": Statement of Mr. Juvigny of France, U.N. Doc. E/AC.32/SR.42, at pp. 33-34, 24 August 1950.

17 Statement of Mr. Juvigny of France, U.N. Doc. E/AC.32/SR.42, at p. 12, 24 August 1950.

18 "Considering that three months seems to be almost universally accepted as the period for which an alien may remain in a country without needing a residence permit ... it would seem that once a refugee, having filed the requisite application, has remained for more than three months, he should be considered 'lawfully staying', even though the authority for his continued sojourn merely is a 'provisional receipt' or its equivalent. ... This leads us to the more general observation, that a refugee is 'residant regulièrement' ('lawfully staying') ... if he is in possession of a residence permit (or its equivalent) entitling him to remain there for more than three months, or if he actually is lawfully present in a territory beyond a period of three months after his entry (or after his reporting himself to the authorities, as the case may be)": A. Grahl-Madsen, The Status of Refugees in International Law (1966), ("Status of Refugees"), at pp. 353-354.

19 See Refugee Convention, supra note 8, at Arts. 14 ("artistic and industrial property"), 15 ("right of association"), 17 ("wage-earning employment"), 19 ("liberal professions"), 21 ("housing"), 23 ("public relief"), 24 ("labour legislation and social security"), and 28 ("travel documents"). In specific circumstances, the benefit of Arts. 7(2) ("exemption from reciprocity") and 17(2) (exemption from restrictive measures imposed on aliens in the context of "wage-earning employment") may also be claimed. 
any more than a decision to bestow an alternative protection label. In short, the label assigned just does not matter.

\section{The Emerging European Protection Regime}

During the first half of the twentieth century, it was Europe which invented and led the way in regularly revising refugee law to meet new circumstances. ${ }^{20}$ Over the last quarter of that century, however, it was Europe which developed the means by which refugee law obligations were too frequently avoided, and sometimes evaded. In the twenty-first century, the projects approved by, and now under consideration within, the European Union afford Europe an extraordinary opportunity to prove not only that it is firmly committed to respect for international refugee law obligations, but more important once again to pioneer the practical implementation of those duties. By taking the lead in the development of a unified and fully rightsregarding procedure for recognizing both Convention refugees and a broader category of persons entitled to international protection, Europe has the ability to reclaim its historical legacy.

Perhaps the most remarkable feature of the evolving European protection system is its rejection - in part, formally, in part, de facto - of past efforts to force refugees to accept an alternative label with less-than-Convention rights. While some important concerns remain at the level of detail (to which I return below), it is important to recognize and to applaud this fundamental shift away from practises which effectively denied refugees their Convention rights.

First, and most important, the Council of the European Union has formally committed itself to the position that "[p]ersons enjoying temporary protection must be able to lodge an application for asylum at any time". ${ }^{21}$ By virtue of this undertaking, a refugee may no longer be forced - as occurred in some states during the reception of Bosnian refugees ${ }^{22}$ - to accept a lesser status with lesser rights. This critical safety valve in the new European temporary

20 See generally Refugee Status, supra note 1, at pp. 1-6.

21 "Council Directive on minimum standards for giving temporary protection in the event of a mass influx of displaced persons and on measures promoting a balance of effort between Member States in receiving such persons and bearing the consequences thereof", Doc. 2001/55/EC, 20 July 2001, at para. 17(1). While states may provide that those applying for "asylum" may not concurrently enjoy the benefits of temporary protection status, the individual concerned must be allowed to resume temporary protected status if the application is refused: id. at Art. 19.

22 See D. Sopf, “Temporary Protection in Europe After 1990: The 'Right to Remain' of Genuine Convention Refugees", (2001) 6 Washington University Journal of Law and Policy, p. 109. 
protection mechanism enables governments to meet their Convention obligations even while establishing a "temporary" protection system which guarantees less-than-Convention rights. ${ }^{23}$ There is no breach of international law where a refugee may choose to accept the benefits of an alternative label (because, for example, that tack involves less fuss and provides a more immediate source of stability), so long as he or she may elect instead to be treated as a refugee, albeit only provisionally pending a formal evaluation of refugee status. $^{24}$

The second important shift in the European system guards against the denial of refugee rights to persons granted admission not to a "temporary" protection regime, but to a more durable system of protection. Under the approach now emerging, Europe is poised to end the de facto strategy of denying refugees their Convention rights by assigning them alternative (durable) protection labels. This analysis may at first seem counter-intuitive: after all, a major feature of the Commission's draft directive on standards for qualification and status is a fairly detailed system of "subsidiary protection". ${ }^{25}$ But the inclusion of this category seems more a function of habit than of substance.

Those recognized as entitled to subsidiary protection rather than Convention refugee status will wear a different label. For the most part, however, the differences in the rights they will enjoy are not such as to raise refugee law concerns, even if someone who is in fact a Convention refugee were to be assigned the alternative label. ${ }^{26}$ For example, the most striking difference in the way the proposal recommends treating refugees and the beneficiaries

23 The European Council on Refugees and Exiles ("ECRE”) has, however, expressed its concern in particular regarding the lesser rights of the beneficiaries of temporary protection status to access health care and to enjoy freedom of internal movement: ECRE, "Information Note on the Council Directive 2001/55/EC of 20 July 2001" (1 September 2001).

24 Importantly, under the Convention's incremental rights regime, an individual seeking verification of refugee status is lawfully present in a state party and therefore provisionally entitled to the benefit of at least the rights which accrue at that level of attachment. See discussion of the rationale for provisional acquisition of basic refugee rights in text supra at notes $3-5$. The specific entitlement of persons seeking recognition of refugee status is addressed in text infra at notes $37-41$.

25 "Proposal for a Council Directive on minimum standards for the qualification and status of third country nationals and stateless persons as refugees or as persons who otherwise need international protection", EU Doc. 14643/02 (Asile 68), 22 November 2002 ("EU Qualification and Status Proposal"), at Chapter V.

26 While persons recognized as refugees have immediate access to integration facilities, equivalent programmes for members of the subsidiary class may be delayed up to one year after status is granted: EU Qualification and Status Proposal, supra note 25, at Art. 31. But because there is no legal duty to provide refugees with integration facilities, the differential approach taken to access by refugees and members of the subsidiary class on this matter does not violate a relevant substantive provision of the Refugee Convention (though its legality 
of subsidiary protection is the length of the residence permit each would be issued (five years for refugees, one year for members of the subsidiary protection class). ${ }^{27}$ Yet because refugees have no right to long-term residence, but only to be protected until and unless their refugee status ceases in accordance with international law, this difference of treatment does not infringe the Convention. ${ }^{28}$

There are, however, two areas in which it is not presently proposed to treat members of the subsidiary class in line with the Refugee Convention. First, they are not granted travel documents in accordance with the requirements of Art. 28 of the Convention. ${ }^{29}$ Second, their access to the labour market is to be denied for up to six months following the date on which their status is granted. ${ }^{30}$ If these two, comparatively minor, divergences were eliminated, there would be no legally cognizable risk if a genuine refugee were instead to be granted only subsidiary protection.

might well be challenged by reference to the duty of non-discrimination under Art. 26 of the International Covenant on Civil and Political Rights).

27 EU Qualification and Status Proposal, supra note 25, at Art. 21.

28 Art. 34 of the Refugee Convention, supra note 8, encourages, but does not require, states to assimilate refugees. The critical concern is that there be no risk of refoulement (Refugee Convention, Art. 33) while respecting other rights. This concern is addressed by the Commission's proposal which requires that the residence permit of a member of the subsidiary protection class be renewed "... until such time as the granting authorities establish that such protection is no longer required": EU Qualification and Status Proposal, supra note 25, at Art. 21(2). So long as this requirement is read in consonance with Art. 16(2), which effectively incorporates the substance of Art. 1(C)(5-6) of the Refugee Convention, the proposal establishes a structure which complies with Art. 33 of the Refugee Convention.

29 The beneficiaries of subsidiary protection are entitled to receive travel documents only if they "are unable to obtain a national passport": EU Qualification and Status Proposal, supra note 25 , at Art. 23. If able to secure the passport of their country of origin, persons granted subsidiary protection are therefore effectively required to entrust their welfare while travelling abroad to the protection of their state of origin - a proposition difficult to square with the logic of granting them a right to be protected from that country by admission to the host country. Indeed, a refugee seeking a passport from his country of origin would be subject to cessation under Art. 1(C)(1) of the Refugee Convention. See Refugee Status, supra note 1, at pp. 192-196.

30 EU Qualification and Status Proposal, supra note 25, at Art. 24. Art. 17 of the Refugee Convention requires immediate access to wage-earning employment once a refugee is lawfully staying in the host country, a duty codified only in the case of persons formally recognized as refugees under the EU proposal, $i d$. It is moreover noteworthy that the proposal fails to recognize (for either refugees or persons granted subsidiary protection) that the right to engage in self-employment accrues earlier than the right to undertake wage-earning employment: Refugee Convention, supra note 8, at Art. 18. But because the right of refugees "lawfully in" a state's territory requires only that refugees be granted the same entitlements in this regard as "aliens generally" (and because EU states do not generally grant "aliens generally" any right to undertake self-employment), the omission may be of no practical consequence. 
The combination of these two changes - no mandatory diversion to temporary protection, and very few legally relevant differences between the entitlements of refugee status and of subsidiary protection - goes a very long distance towards remedying the risk of denying refugees their rights by the assignment of alternative protection labels. These measures should be applauded as a reaffirmation of the true meaning of the Refugee Convention, ${ }^{31}$ and deserve the strong support of refugee scholars and advocates. Indeed, they are the critical foundation upon which to consider building a unified decision-making structure for all categories of persons entitled to international legal protection. ${ }^{32}$

\section{Problems Remaining}

I would be remiss, however, if I did not point out what I view as three important deficiencies in the common European asylum policy as presently conceived. I do so not to take anything away from the extraordinary significance of the two shifts just described, but in the hope that it is not too late to reconsider at least some details of the more coherent refugee policy now being constructed.

First, in considering the question of minimum standards for the reception of persons seeking protection, the approach proposed in the Commission's current draft directive treats "asylum seekers" (or "applicants") as a category of persons not entitled to invoke rights under the Refugee Convention. ${ }^{33}$ While it is true that an individual seeking recognition of refugee status is not necessarily a refugee, it is also true that an individual is necessarily a refugee - and hence entitled to claim the rights of refugees - prior to the formal verification of his or her status:

A person is a refugee within the meaning of the 1951 Convention as soon as he fulfils the criteria contained in the definition. This would necessarily occur prior to the time at which his refugee status is formally determined.

Recognition of his refugee status does not therefore make him a refugee

31 Thomas Spijkerboer arrives at a similar conclusion by analysis of the personal scope of the various European protection categories: T. Spijkerboer, "Subsidiarity in asylum law: the personal scope of international protection", in D. Bouteillet-Paquet (ed.), Subsidiary protection of refugees in the European Union: complementing the Geneva Convention?, p. 19 (2002).

32 See text infra following note 71.

33 "Proposal for a Council Directive laying down minimum standards on the reception of applicants for asylum in Member States", Doc. 15398/02, Asile 78, 13 December 2002 ("EU Reception Standards Proposal"), at Art. 2(c). 
but declares him to be one. He does not become a refugee because of recognition, but is recognized because he is a refugee. ${ }^{34}$

The declaratory nature of refugee status means that a general policy of failing to recognize Convention rights until and unless refugee status is affirmatively verified will in practise deny rights to persons clearly entitled to protection under the text of the treaty. ${ }^{35}$ Unless status assessment is virtually immediate, a state adhering to such a policy will be unable to meet its duty to implement the Refugee Convention in good faith. ${ }^{36}$

This dilemma can only be resolved by granting any person who claims to be a Convention refugee the provisional benefit of at least the more basic rights set by the Convention. ${ }^{37}$ Governments that wish to be relieved of the presumptive (if minimalist) responsibility towards all asylum seekers have the legal authority to take steps to expedite formal determination of refugee status, including by resort to a fairly constructed procedure for "manifestly unfounded claims" if necessary. ${ }^{38}$ Convention rights can then be withdrawn from persons found not to be refugees. But any effort to withhold all Convention rights pending status determination is irreconcilable to a treaty that explicitly provides for rights to accrue before a refugee is found to be eligible to remain in the asylum country. ${ }^{39}$

34 Handbook, supra note 11, at para. 28.

35 The spirit of the Convention's incremental rights regime was recognized, albeit indirectly, in a now-abandoned clause of the EU Reception Standards Proposal, EU Doc. COM(2001) 181 final, 3 April 2001 (“Apr. 2001 Draft of EU Reception Standards Proposal”), at Preamble, para. 8: "The living conditions of applicants for asylum should in all cases be dignified, but they should be improved when applications are considered admissible and not manifestly unfounded".

36 Vienna Convention, supra note 5, at Art. 26. "The principle of good faith underlies the most fundamental of all norms of treaty law - namely, the rule pacta sunt servanda.... Where a third party is called upon to interpret the treaty, his obligation is to draw inspiration from the good faith that should animate the parties if they were themselves called upon to seek the meaning of the text which they have drawn up": I. Sinclair, The Vienna Convention on the Law of Treaties, pp. 119-120 (1984).

37 Specifically, states must at this point grant refugees the provisional benefits of those rights which inhere by virtue of "lawful presence". See text supra at notes 14-15 for a description of these rights.

38 Manifestly unfounded claims are "those which are clearly fraudulent or not related to the criteria for the granting of refugee status laid down in the 1951 United Nations Convention relating to the Status of Refugees nor to any other criteria justifying the granting of asylum": Executive Committee of the High Commissioner's Programme, Conclusion No. 30 (XXXIV) (1983), at para. (d).

39 Since the Convention grants rights when a refugee is "in" and "lawfully in" a state - not just once he or she is "lawfully staying" or durably residing there - it is difficult to justify a 
In fact, the only international legal relevance of having entered a system of refugee status verification is that the rights to which the individual is provisionally entitled are enhanced. This is because an individual who seeks recognition of refugee status in a state party to the Convention, and who has provided authorities with the information that will enable them to consider his or her entitlement to refugee status - in particular, details of personal and national identity, and the facts relied upon in support of the claim for admission - has ceased to be irregularly present. ${ }^{40}$ Once having met the administrative requirements established by the state to consider which persons who arrive without authorization should nonetheless be allowed to remain there as refugees, the refugee is lawfully present in that country. ${ }^{41}$

Yet the current Commission proposal grants governments a general prerogative to assign refugees to "an area" ${ }^{42}$ and even allows the reception country to "decide on the residence of the asylum seeker" where necessary to ensure "the swift processing and effective monitoring of his or her application". 43 This approach conflicts with Article 31(2) of the Refugee Convention, which grants states only a limited prerogative to detain a person seeking refugee status until his or her identity is established, basic security concerns are investigated, and the asylum seeker's cooperation is secured for purposes of conducting all necessary investigations into his or her claim to protection. Once these concerns have been addressed, the refugee's presence has been regularized in the receiving state, and refugee-specific restrictions on freedom of movement must come to an end in accordance with Article $26 .^{44}$

construction suggesting that no Convention rights need be honoured pending the results of an inquiry intended to determine eligibility to remain in the asylum state.

40 Presence is lawful in the case of "... a person ... not yet in possession of a residence permit but who had applied for it and had the receipt for that application. Only those persons who had not applied, or whose applications had been refused, were in an irregular position": Statement of Mr. Rain of France, U.N. Doc. E/AC.32/SR.15, at 20, 27 January 1950.

41 Grahl-Madsen suggests one potentially important exception to this general principle. He argues that a refugee who is detained pending verification of his claim to Convention refugee status (presumably on grounds that meet the justifiability test of Art. 31(2) of the Convention) can no longer be considered to be "lawfully" present: Status of Refugees, supra note 18, at pp. 361-362. This conclusion is clearly tenable, though not based on decisions reached during the drafting process. A detained refugee claimant would still be entitled to those rights that are not restricted to refugees whose presence is lawful, i.e. rights which inhere in all refugees, and in refugees who are physically present in the territory of a state party.

42 EU Reception Standards Proposal, supra note 33, at Art. 7(1).

43 Ibid., at Art. 7(2).

44 On the other hand, since access to a state's public welfare system need not be granted until a refugee is "lawfully staying" in the asylum country, Art. 23 of the Refugee Convention is not infringed by the draft provision that would allow Member States to withdraw "material 
The current proposal moreover authorizes states to delay access by refugee children to primary education, and guarantees them no more than education "under similar conditions" to those enjoyed by nationals. ${ }^{45}$ The Refugee Convention, in contrast, provides for immediate access to "... the same treatment as is accorded to nationals with respect to elementary education." 46

Nor is there any basis in international law for the proposed rule authorizing the punitive reduction or withdrawal of (unspecified) rights of refugee status claimants based, for example, on their not having claimed refugee status "as soon as reasonably practicable after arrival", having breached directives which purport to restrict their freedom of internal movement, or for being dilatory in meeting their duties to provide information to authorities. ${ }^{47}$ It was explicitly decided in drafting Art. 2 of the Refugee Convention that there should be no possibility of withdrawing refugee rights for reasons insufficient to justify either expulsion or the withdrawal of refugee status. As the Danish representative to the Conference of Plenipotentiaries insisted,

What was important was that the refugee should not constitute a problem, and that he should conform to the laws and regulations to which he was subject. When he failed to do so, appropriate sanctions should be applied, and repeated violations of the regulations might reasonably warrant expulsion. Until he was expelled, however, he should be treated in accordance with the provisions of the Convention and be subject only to such sanctions as were applicable to other law-breakers. ${ }^{48}$

reception conditions" (falling short of a denial of the essentials of life) if an individual seeking recognition of refugee status were to refuse to live in an assigned place: EU Reception Standards Proposal, supra note 33, at Art. 7(4).

45 Under the current proposal, access to education may be postponed for up to three months, which period may be extended to up to one year: EU Reception Standards Proposal, supra note 33, at Art. 10(2). Not only does the proposal authorize education "under similar conditions" as those granted to citizen children, but it expressly contemplates that education might be offered to refugees only in "accommodation centres": id. at Art. 10(1).

46 Refugee Convention, supra note 8, at Art. 22(1).

47 EU Reception Standards Proposal, supra note 33, at Art. 16. This provision is, however, an improvement on an earlier draft which recommended inter alia the ability to reduce or withdraw access to the labour market for the oddly framed ground of "negative behaviour": April 2001 EU Draft Asylum Applicants Proposal, supra note 35, at Art. 13(3).

48 Statement of Mr. Hoeg of Denmark, U.N. Doc. A/CONF.2/SR.4, at pp. 4-5, 3 July 1951. The only exception is the right of refugees to receive travel documents, which may be suspended under the explicit terms of the Convention where required by "compelling reasons of national security or public order": Refugee Convention, supra note 8, at Art. 27. The inappropriateness of withdrawing rights as a form of penalty has recently been noted by the European Council on Refugees and Exiles. "ECRE believes that asylum seekers who engage in criminal behaviour, or are considered a threat to national security, should be dealt with according to the national criminal law of the host state and should be treated equally with nationals. ... Asylum seekers who do not comply with the rules governing the provision 
Thus, failure to meet a reporting obligation can be met with a proportionate sanction, or concealment of financial resources with prosecution for fraud or a suit for compensation. ${ }^{49}$ But a general prerogative to withdraw refugee rights for such matters - euphemistically described in the proposal as the authority to withdraw "reception conditions" 50 - is an unduly blunt and legally unwarranted invitation to violate Convention rights.

A second area of concern is the guidelines for the interpretation of refugee status. There are some important, positive aspects to the proposed rules for applying the refugee definition. At a basic level, the (belated) decision to embrace binding common standards for the assessment of refugee status is vital to the legal integrity of a system, such as that established by the Dublin Convention, which forces refugees to claim protection in a designated state of arrival. ${ }^{51}$ More specifically, the proposal resolves perhaps the most contentious question in European practice by clearly affirming a comprehensive understanding of legally pertinent sources of risk. ${ }^{52}$ It also clearly links analysis of harms within the ambit of "persecution" to core norms of human rights law. ${ }^{53}$ But in several other respects, the definitional proposal is cause for concern. For example:

of accommodation or healthcare, or conditions of employment, education or training, may, after proper consideration of their circumstances, find those rights subject to sanctions equivalent to those imposed upon nationals. ... All sanctions relating to asylum seekers should be part of a national regulatory framework, backed by law, in order to avoid inconsistency and discrimination": ECRE, "Summary of ECRE's position on the reduction or withdrawal of reception conditions for asylum seekers, with reference to the Proposal for a Council Directive laying down minimum standards on the reception of applicants for asylum in Member States" (February 2002).

49 Indeed, the proposal recognizes as much, providing that - in addition to "reducing or withdrawing reception conditions" - states may also seek restitution from an asylum seeker who has received subsistence funds by having failed to disclose that he or she had sufficient funds to meet personal needs: EU Reception Standards Proposal, supra note 33, at Art. 16(1)(b).

50 "Reception conditions" are defined to be "... the full set of measures that Member States grant to asylum seekers in accordance with this Directive": EU Reception Standards Proposal, supra note 33, at Art. 2(i).

51 See e.g. Adan and Aitseguer v. Secretary of State for the Home Department, [2001] 2 WLR 143 (U.K. House of Lords).

52 Specifically, "actors of persecution" are defined to include "(a) the State; (b) parties or organizations controlling the State or a substantial part of the territory of the State; [and] (c) non-State actors, if it can be demonstrated that the actors mentioned under sub-paragraphs (a) and (b), including international organizations, are unable or unwilling to provide protection ...": EU Qualification and Status Proposal, supra note 25, at Art. 9.

53 EU Qualification and Status Proposal, supra note 25, at Art. 11(1). Regrettably, however, the rules for interpretation of an international refugee definition refer solely to rights as defined under the European Convention for the Protection of Human Rights and Fundamental Freedoms. Not only is this of concern as a matter of treaty interpretation, but it may make it 
1. The most recent draft omits any reference to the fundamentally objective nature of the refugee inquiry, and specifically to the duty of the applicant to show only a "reasonable possibility" of risk. ${ }^{54}$

2. There is no clear recognition that a well-founded fear of being persecuted does not require targeting or individualized risk, but may be established where the individual concerned demonstrates risk to a group of persons defined by a Convention ground of which he or she is found to be a member. ${ }^{55}$

3. The rules governing sur place claims are internally inconsistent and overly rigid. ${ }^{56}$

more difficult for applicants to secure access to refugee protection based on even critical risk to economic rights (which are not explicitly protected by that treaty).

54 In an earlier draft, it was explicitly affirmed that the focus of the inquiry was "whether the applicant's fear of being persecuted or exposed to other serious and unjustified harm in the country of origin is objectively established, in that there is a reasonable possibility that the applicant will be persecuted or otherwise subjected to serious harm if returned to the country of origin": "Proposal for a Council Directive on minimum standards for the qualification and status of third country nationals and stateless persons as refugees or as persons who otherwise need international protection”, EU Doc. COM(2001) 510 final, 9 September 2001 ("Sept. 2001 Draft of EU Qualification and Status Proposal"), at Art. 7(b). The present version contains a variety of rules for the assessment of "facts and circumstances", but fails to state the overarching evidentiary test that must be satisfied: EU Qualification and Status Proposal, supra note 25, at Art. 7.

55 In the 1996 European Union Joint Position, O.J. L63, 13 March 1996 ("EU Joint Position"), at Art. 2, it was expressly observed that "[i]n practise it may be that a whole group of people are exposed to persecution. In such cases, too, applications will be examined individually, although in specific cases this examination may be limited to determining whether the individual belongs to the group in question".

56 The present version of Art. 7(3)(d) is oddly framed in that it suggests a need specifically to focus on whether an applicant has engaged in activities "for the sole or main purpose of creating the necessary conditions for making an application for international protection", but concludes by indicating that such evidence is pertinent simply to satisfaction of the ordinary standard, namely "whether these activities will expose the concerned person to persecution or serious harm if returned to that country": EU Minimum Standards Proposal, supra note 25, at Art. 7(3)(d). In a subsequent draft article, it is suggested in apparent contradiction of Art. 7(3)(d) that a well-founded fear in such circumstances exists in particular "... where it is established that the activities relied upon constitute the expression and continuation of convictions or orientations held in the country of origin": id. at Art. 8(2). Not only does this approach seem narrower than that set by Art. 7(3)(d), but it is not explicitly acknowledged that the fact that the activities engaged in outside the home country represents a continuation of convictions held in the country of origin is a sufficient, but not a necessary condition for recognition of a sur place claim. The non-absolutism of a continuity requirement was recognized, at least in part, in the EU Joint Position, supra note 55, at Art. 9(2): "However, such continuity must not be a requirement where the person concerned was not yet able to establish convictions because of age". To similar effect, see judicial decisions from Belgium (V.B.C., 12 Oct. 1992, C.P.R., 13 September 1990, cited in J.-Y. Carlier, Who Is a Refugee? (1997), at 
4. The failure to treat the failure of state protection as a component of the risk of "being persecuted" may undermine genuine refugee claims where the nexus is between a Convention ground and the state's failure adequately to respond to the risk. ${ }^{57}$

5. Despite the Convention's focus on the applicant's real predicament, including situations in which the risk derives from state inability to protect, the proposal illogically suggests that refugee status may be denied where the state of origin has engaged in "reasonable" protective measures, with no requirement that these measures in fact reduce the risk below a "well-founded fear." 58

6. The proposed rule denying refugee status to persons who can be returned to an area under the authority of "parties or organizations ... controlling the State or a substantial part of the territory of the State" has no basis whatever in the Refugee Convention. The Convention definition is concerned not with whether "protection" of some kind is available, but

p. 71); Germany (BverwG 9 C 143.90, 1992; 2BvR 1587/90, 1992; 2 BvR 749/89, 1990); and the United Kingdom, (Yavari, [1987] Imm. A.R. 138, at p. 141, cited in J.-Y. Carlier 1997, $i d$. at p. 581). The recommendation to respond to self-serving (but nonetheless genuine) sur place claims by reducing benefits "[w]ithin the limits set out by the Geneva Convention" is, in my view, a sensible and proportionate response to such claims: EU Qualification and Status Proposal, supra note 25, at Art. 18(6).

57 EU Minimum Standards Proposal, supra note 25, at Arts. 11(1), 11(3). This gap is of particular concern in many refugee claims by women. The importance of understanding the risk of "being persecuted" to have two components (serious harm and failure of state protection) was cogently illustrated by Lord Hoffmann in the seminal decision of Shah and Islam v. Secretary of State for the Home Department, [1999] 2 AC 629 (House of Lords): “... [S] uppose the Nazi government ... did not actively organize violence against Jews, but pursued a policy of not giving any protection to Jews subjected to violence by neighbours. A Jewish shopkeeper is attacked by a gang organized by an Aryan competitor. ... The competitor and his gang are motivated by business rivalry and the desire to settle old personal scores.... Is he being persecuted on ground of race? ... [I]n my opinion, he is. An essential element in the persecution, the failure by the authorities to provide protection, is based upon race. It is true that one answer to the question 'why was he attacked?' would be 'because a competitor wanted to drive him out of business.' But another answer, and in my view the right answer in the context of the Convention, would be 'he was attacked by a competitor who knew he would receive no protection because he was a Jew'." See also my "The Michigan Guidelines on Nexus to a Convention Ground", (2002), 23(2) Michigan Journal of International Law, p. 207.

58 EU Minimum Standards Proposal, supra note 25, at Art. 9A(2). While clearly absolute protection is beyond any reasonable expectation, there is no good reason to deny refugee status where whatever efforts a state makes do not, in fact, bring the risk below the Convention's litmus test of a real chance or serious possibility of being persecuted. To hold otherwise is to favour formalism over an analysis of the reality of risk. This "best efforts" understanding has, however, been embraced by the House of Lords in its decision of Horvath v. Secretary of State for the Home Department, [2000] 3 All E.R. 577 (6 July 2000). 
rather with whether the applicant can avail himself or herself of " . . the protection of that country (emphasis added)."

7. The suggested approach to "internal protection" unhelpfully proposes an inquiry into the reasonableness of return rather than a Convention-based analysis of whether an applicant can, in fact, access meaningful national protection in another part of his or her own country. Indeed, as recently redrafted, a claim may even be denied on grounds of a theoretical internal protection alternative despite "technical obstacles to return." 60

8. The meaning of "political opinion" has been vaguely and unhelpfully defined as an opinion "on a matter related to the potential persecutors. ..."61

59 EU Minimum Standards Proposal, supra note 25, at Art. 9. As observed by the Supreme Court of Canada, "[t]he international community was meant to be a forum of second resort for the persecuted, a 'surrogate,' approachable upon failure of local protection. The rationale upon which international refugee law rests is not simply the need to give shelter to those persecuted by the state, but, more widely, to provide refuge to those whose home state cannot or does not afford them protection from persecution": Attorney-General of Canada v. Ward (1993) 2 SCR 689 at p. 716. To the same effect, in 'Applicant A' and Anor v. Minister for Immigration and Ethnic Affairs and Anor, (1997) 190 CLR 225 at p. 248, Dawson J held that it is a "well-accepted fact that international refugee law was meant to serve as a 'substitute' for national protection where the latter was not provided due to discrimination against persons on grounds of either civil or political status." Most recently, in Horvath v. Secretary of State for the Home Department, [2000] 3 All E.R. 577, Lord Hope observed: "The general purpose of the Convention is to enable a person who no longer has the benefit of protection against persecution for a Convention reason in his own country to turn for protection to the international community" (p. 581); and per Lord Lloyd: "Thus the principle of surrogate protection finds its proper place in the second half of art $1 \mathrm{~A}(2)$. If there is a failure of protection by the country of origin, the applicant will be unable to avail himself of that country's protection" (at p. 589). The purport of the current EU draft clause is clear from the language proposed in an earlier draft, in which "state" protection was defined to include protection provided by "... stable quasi-State authorities who control a clearly defined territory of significant size and stability ...": September 2001 Draft of EU Qualification and Status Proposal, supra note 54, at Art. 9(3). Yet as a matter of international law, there is clearly no such thing as a "quasi-state."

60 EU Minimum Standards Proposal, supra note 25, at Art. 10. See generally my "The Michigan Guidelines on the Internal Protection Alternative", (1999), 21(1) Michigan Journal of International Law, p. 131. This understanding is developed in detail in J. Hathaway and M. Foster, "The Internal Protection/Relocation/Flight Alternative as an Aspect of Refugee Status Determination", in Refugee Protection in International Law: UNHCR's Global Consultations on International Protection (forthcoming, Cambridge University Press).

61 EU Minimum Standards Proposal, supra note 25, at Art. 12(1)(e). An earlier draft more sensibly took the view that "political opinion" was defined as "the holding of, or the being conceived of as holding, an opinion on a matter related to the State or its government or its policy, whether or not that opinion has been acted upon by the applicant": "Proposal for a Council Directive for minimum standards for the qualification and status of third country nationals and stateless persons as refugees or as persons who otherwise need international 
9. The definition of a "particular social group" is now predicated on satisfaction of both the "protected characteristics" and "social perception" tests. ${ }^{62}$ In the result, groups defined by sexual orientation or gender are no longer recognized as clear examples of particular social groups, ${ }^{63}$ but may qualify only "depending on the circumstances in the country of origin., 64

A third and final set of concerns is the elaboration of the rights proposed to be granted to refugees and members of the subsidiary protection class. While it is true that Art. 18(1) of the draft recognizes the pre-eminence of refugee rights as set by the Refugee Convention, ${ }^{65}$ this begs the question of why some rights are explicitly elaborated in the EU proposal, while others are not mentioned at all. ${ }^{66}$ For example, refugees lawfully staying in a state party must be guaranteed the same right to join trade unions and other non-political

protection”, EU Doc. 9038/02, Asile 25, 17 June 2002 (“June 2002 Draft of EU Qualification and Status Proposal"), at Art. 12(e).

62 That is, the members of the group must share a common innate or fundamental characteristic, and the group must be perceived as being set apart from society in general: EU Qualification and Status Proposal, supra note 25, at Art. 12(d). In practise states tend to embrace either the protected characteristics approach or the social perception approach to the definition of a particular social group - but not to require that both tests be met, as is proposed here. Confusion on this point is likely attributable to UNHCR's recent advocacy of a merger of these two approaches: UNHCR, "Guidelines on International Protection: 'Membership of a particular social group' within the context of Article 1A(2) of the 1951 Convention and/or its 1967 Protocol relating to the Status of Refugees", U.N. Doc. HCR/GIP/02/02, 7 May 2002.

63 It was earlier proposed that only the protected characteristics test need be satisfied, in which case groups defined by sex (or gender) and sexual orientation were clearly included. “... [T] he concept of social group shall include a group which may be defined in terms of certain fundamental characteristics, such as sexual orientation, age or gender, as well as groups comprised of persons who share a common background or characteristic that is so fundamental to identity or conscience that those persons should not be forced to renounce their membership": June 2002 Draft of EU Qualification and Status Proposal, supra note 61, at Art. 12(d).

64 EU Qualification and Status Proposal, supra note 25, at Art. 12(d). "Circumstances in the country of origin" are, of course, relevant to determine whether or not being a member of the group gives rise to a well-founded fear of being persecuted. But a particular social group must be capable of definition independently of those circumstances, otherwise a risk of circular reasoning exists ("my fear is by reason of membership of a particular social group, which group exists because there is a risk of it being persecuted").

65 EU Qualification and Status Proposal, supra note 25, at Art. 18(1).

66 The EU Qualification and Status Proposal, supra note 25, does not address the rights which inhere by virtue of Refugee Convention Art. 13 (property rights), 14 (artistic and industrial property rights), 15 (freedom of association), 16(1) (access to the courts), 16(2) (access to legal aid), 19 (right to engage in professional practice), 20 (participation in rationing systems), 25 (administrative assistance), 29 (tax equity), 30 (asset transfer), 31 (freedom from penalization and arbitrary detention), or 34 (access to naturalization). While one answer is that many of these rights are guaranteed under other regional human rights standards, so too are 
associations as EU nationals; ${ }^{67}$ they are entitled to access legal aid on terms of equality with citizens; ${ }^{68}$ and they have an unqualified right to access both a host state's courts ${ }^{69}$ and the assistance of an agency charged with enforcing their Convention rights. ${ }^{70}$ Yet none of these legal requirements is mentioned.

My point is not that these rights will in practise be withheld from refugees in the European Union. But a less than sanguine message is implied by a directive which refers only selectively to Convention rights. In my view, it would be better simply to refine Art. 18(1) to declare that all Convention rights will be granted to persons recognized as entitled to international protection, with explicit reference being made only to those rights - such as the right to engage in wage-earning employment - where the EU proposes to grant protection more generously than states are required to do by the Refugee Convention. ${ }^{71}$

\section{Preliminary Thoughts on a Unified Procedure}

The essential message I wish to convey is a simple one. Europe appears committed to two fundamentally important policy shifts which lay the groundwork for a legally tenable unification of the procedures for assessment of both refugee status and a more broadly conceived subsidiary protection status. Member States have already agreed not to force refugees into alternative protection regimes offering less-than-Convention rights, and are now poised to commit themselves to the effective assimilation of refugees and members of the broader class for purposes of rights entitlement. So long as the details of the latter shift can be refined in the three ways I have just outlined - acceptance of the true scope of the Convention rights of persons awaiting a decision on recognition of their refugee status, more careful elaboration of the scope of refugee status, ${ }^{72}$ and the drafting of a more legally exact catalogue of

some of the rights which are addressed by the Proposal, eg. access to employment, education, and welfare.

67 Refugee Convention, supra note 8, at Art. 15.

68 Ibid., at Art. 16(2).

69 Ibid., at Art. 16(1).

70 Refugee Convention, Art. 25.

71 Art. 17 of the Refugee Convention, supra note 8, requires state parties to grant refugees only the same right to work as is enjoyed by most favoured foreigners, whereas the EU Minimum Standards Proposal requires refugees to be treated as nationals for purposes of access to employment: EU Qualification and Status Proposal, supra note 25, at Art. 24(1).

72 A positive feature of the most recent draft is a clear and principled definition of the forms of "serious harm" which warrant the granting of subsidiary protection status. These include the risk of "(a) death penalty or execution; or (b) torture or inhuman or degrading treatment or punishment ...; or (c) serious and individual threat to a civilian's life or person by reason 
the rights that inhere in persons found to be in need of international protection - then there is no international legal impediment to a unified procedure for the assessment of both refugee and subsidiary protection statuses.

But assuming these baseline conditions are met, should we, as a matter of policy, endorse the idea of a common assessment procedure for refugee and subsidiary protection statuses? I believe that there are at least two important arguments in favour of a unified procedure, which ultimately link in a profound way to Europe's ability to complete its project of substantive harmonization in a genuinely rights-regarding way.

First, a unified procedure to assess both refugee and subsidiary protection statuses will be much less expensive. This fairly obvious point is most often thought to be an argument which appeals only to governments. But procedural unification also presents an opportunity for refugee advocates credibly to insist on a truly sufficient investment of resources in the unified mechanism. Simply put, refugees can be treated more fairly for less money than it would cost to fund a sequential model comprised of two, comparatively thinly resourced, assessments.

A single fact-finding hearing is in my view sufficient, so long as it is a genuinely fair and impartial hearing. Decision-makers should be independent and carefully selected for breadth of experience and knowledge of not just law, but also of foreign politics, culture, and social conditions. They should be given the time and back-up resources needed to do their job well. Those seeking protection should benefit from truly competent counsel and interpreters, and have access to legal and country of origin data. Reasons for decision should be given so that the single appeal or review - which I would see as sufficient even if restricted to issues of law and jurisdiction, though with the authority to order a new hearing on the facts where warranted can proceed on the basis of a clear record of the initial factual and legal determinations.

Under such a system, those seeking protection would truly be treated in accordance with our own principles of adjudicative fairness, even as taxpayers reap savings compared with either the expense of the current muddle of multiple, usually inadequate, assessments and reviews, or with the cost of moving to a two-step model to assess refugee status, then subsidiary protection status.

of indiscriminate violence in situations of international armed conflict": EU Qualification and Status Proposal, supra note 25, at Art. 15. These forms of serious harm correspond to the grounds for non-return under regional and international human rights law, and to the duty of non-return adjudged by some courts to be derived from international humanitarian law. The only minor concern is whether a threat to life or person in the context of armed conflict can sensibly be described as both "individual" and "indiscriminate": a reference to a risk faced by the applicant or a group of which he or she is a part would be more exact. 
Second and related, a procedure such as I have described - one high quality hearing, one thoughtful review or appeal - would in most cases dramatically speed up the time required to assess protection requests. Again, a speedier process is ordinarily thought to be of interest mainly to governments. But in fact, it also benefits individual persons entitled to protection, as they can much more quickly get on with their lives, planning and living with reasonable confidence and security.

Even more important, a fair but speedier process is also of critical importance to the health of the refugee law system as a whole. As I see it, an unnecessarily protracted procedure is one of the most powerful weapons in the arsenal of those who oppose the admission of refugees and others entitled to international protection. Where the amount of time required finally to determine whether an applicant is entitled to remain is so long that personal and familial equities are inevitably built up in the reception state, it understandably becomes increasingly difficult for governments - legally, politically, and socially - to remove even those ultimately found to have made non-genuine refugee claims.

There is therefore some truth to the common assertion that refugee processing systems can amount de facto to a back door immigration system. I believe that it is in all our interests to do what we can to close that back door, thereby defusing unwarranted restrictionist pressures and the non-entrée policies which they breed. Our best ally to that end is a system of expeditious status assessment, in which the number of procedural steps is reduced to the bone. If those seeking protection in the European Union were to have direct and immediate access to a hearing in which both refugee and subsidiary protection status were to be assessed, with a single, unified review or appeal of both issues, there would rarely be enough time for a non-protection based argument against removal to be built up. Moreover, the incentive to abuse the protection system would also be reduced under a speedier procedure of this kind, as the time spent in Europe by non-genuine claimants would less frequently warrant the investment of funds that is usually required to get here.

My intuition is that reaching consensus on the basic structure of a streamlined system for the processing of protection claims may well be critical to Europe's ability to meet its goal of agreeing to a common asylum system based on respect for international law. Having committed itself to two courageous and principled steps - abolition of mandatory diversion to "temporary" protection, and the effective assimilation of refugees and other persons entitled to international protection against return - there is a growing sense among some governments that the content of the asylum system must not be too liberal, lest it amount to a magnet for unfounded claims. 
This fear may well explain the apparent determination to treat asylum seekers as outside the ambit of refugee rights, or artificially to circumscribe the scope of refugee status and the content of protection standards. The present challenge is to resist these easy but legally problematic options, and instead to harness procedural efficiency as the primary means by which to deter abuse. Anything less will amount to a failure by Europe to achieve its self-imposed goal of building a common asylum system "based on the full and inclusive application" ${ }^{, 73}$ of international law.

73 Conclusion of the European Council, Tampere, 15-16 October 1999. 
